\title{
ANALYSIS OF THE PROBLEMS FACED BY NEWLY APPOINTED \\ ELEMENTARY SCHOOL EDUCATORS IN PAKISTAN
}

\author{
MUHAMMAD LATIF JAVED, PHD \\ Lecturer Department of Education, \\ The Islamia University of Bahawalpur, Pakistan \\ Bahawalnagar Campus. \\ Email: latif.javed@iub.edu.pk \\ MUHAMMAD NADEEM JAVED \\ Senior Subject Specialist (physics) \\ Fauji Foundation Education System, Pakistan \\ Email: nadeemjaved2009@yahoo.com \\ ASIF ALI CH, \\ Senior Science Teacher, \\ GOVT. PHS, NO-2, Mirpur, Azad Jammu \& Kashmir \\ Email: asif_10200@yahoo.com
}

\begin{abstract}
This study critically examines the problems of newly appointed Elementary School Educators in Punjab. For this purpose a critical review of existing literature was carried out. On the basis of deeper and critical investigation into the literature, the study found that Primary School Science Educators are most depressed group after being selected as Science Educators they poorly managed without considerations of their gender differences. The Policy of Recruitment \& Selection is not employee friendly, but only to fill the vacancies. There is no concept of proper transport and house facility even for young females Educators who can't make daily comeback nor live at their work places The System of monitoring is weak and traditionally characterized having no effect and blamed as biased mechanism. The study recommended that the problems of Science Educators can be solved by making the policy more Convenient for local Educators then the vacancy filling from far-flung residents.
\end{abstract}

Keywords: Analysis, Science Educators, Gender differences, Monitoring

\section{INTRODUCTION}

According to Adams (1998, p.62) Education is a vital process of the development of any society. It is considered one of the main elements of structure of a society. There is no doubt that Education is a vital process of the development of any society. Education is 
the source of all types of inspirations of the generation to become strong nation in the world. It is an established fact that in the world only those nations have made progress and development which have a sound education system (Ball, 1990). Education develops individuals. It creates awareness among the people about life and its challenges in the world. It fills empty minds with ideas and creativity. Thus educationally sound nations play leadership role in the world (American Federation of Teachers, 2000).

Since its independence, Pakistan lagged behind in national development and progress due to weak education system. The system of education could not able to make progress due to many factors such as un realistic policies, frequent military interventions, parochial feudal and state politicians, non-serious attitude of bureaucracy, misuse of funds, fragile civil society and weak democracy. In this way with the other sector of education system the system of primary education was deliberately neglected in the country. Instead of developing the nation on the basis of free and quality education, the system was hijacked by so-called monsters of democracy and development (Zafar, 2003).Teachers of all sector are called social engineers and if the engineers remained unsatisfied and vulnerable for their future, they will bring the nation at her back foot.

At primary level the concept of teaching is quite different as compare to secondary and higher education, because at primary level young minds required fully devoted and energized educators free from their own worries to nourish the early buds. The present government of Punjab working for the last one decade to make education system more advance and according to the needs of the people. The efforts are appreciable in many aspects of different segments of education. There is no doubt about merit and transparency in the process of induction of teachers, but the criteria and policy guidelines are not so realistic.

The current policy of recruitment and selection is applied only for fulfilling the vacant posts but not to make sure to keep the teachers remain working regularly and permanently in the department. The process of recruitment and selection has its two phases i.e. one for tehsil level and other for district level, the most problematic aspect of the policy is the district quota system and criteria which make the situation more adverse with its applications and implementation. 
Research Studies have found that there are many basic indictors regarding structural management and social problems in the primary education system of Punjab Pakistan. The conditions of primary schools in the rural areas are more deplorable than in the urban areas. The schools do not have even teachers to conduct teaching and learning programs (Government of Punjab, 2004). In many schools local people keep their animals. Many schools are being used as temporary shelter by gypsies and refugees. As a result of this situation, these schools are producing incompetent, poor skilled and poor knowledgeable students for the higher education in the country. There is no proper system of transport and availability of residence. On one side there is every facility available to children studying in elite schools of the country and on the other hand are the dilapidated schools where shabby children study without clean drinking water and basic health facilities for them and their teachers and other basic facilities (Hussain, 2001).

Recruitment and selection also has an important role to play in ensuring teacher performance and positive organizational outcomes. It is often claimed that selection of teachers occurs not just to replace departing teachers or add to a workforce but rather aims to put in place teachers who can perform at a high level and demonstrate commitment (Ballantyne, 2009). Recruitment and selection is often presented as a planned rational activity, comprising certain sequentially-linked phases within a process of employee resourcing, which itself may be located within a wider HR management strategy. Bratton and Gold (2007, p 239) differentiate the two terms while establishing a clear link between them in the following way:

Recruitment is the process of generating a pool of capable people to apply for employment to an organization. Selection is the process by which managers and others use specific instruments to choose from a pool of applicants a person or persons more likely to succeed in the job(s), given management goals and legal requirements. In setting out a similar distinction in which recruitment activities provide a pool of people eligible for selection, Foot and Hook (2005, p 63) suggest that: 'although the two functions are closely connected, each requires a separate range of skills and expertise, and may in practice be fulfilled by different staff members. The recruitment activity, but not normally the selection decision, may be outsourced to an agency. It makes sense, therefore, to treat each activity separately. 
The study is significant in many ways but the following two aspects are most important; these include the planners and future researchers. Theoretically the policy of Recruitment \& Selection will be readdressed keeping in view the needs and realities of the primary School Science Educators. On technical grounds the Policy may also be revised so that local SEs may get full benefits from the criteria set for Recruitment \& Selection. In this way the study will help the planners to see the actual ground realties to implement the policy for the purpose of Recruitment \& Selection. The future Researchers will be able get more data for conducting research for this field. The objectives of the study are (1) to identify the main problems of newly appointed School Educators in Punjab, (2) to examine critically the causes of the problems of newly appointed School Educators in Punjab and (3) To suggest possible long term solutions on the basis of the study for the problems of newly appointed School Educators in Punjab.

\section{DATA AND METHODOLOGY}

\section{A. METHODS}

This research study aims to find out the main causes of the problems faced by primary school Science Educators in Punjab. For this purpose, a large amount of literature was critically reviewed. The study was descriptive in nature therefore no experiment was needed to conduct; the analysis of the problems and its causes is presented below.

\section{B. POPULATION}

The all Primary School Science Educators selected during (2012-13) of the Punjab Province of Pakistan are the Population of the study. The total number of SEs in the province remained 7500 in these two years.

\section{SAMPLE AND SAMPLING TECHNIQUE}

A descriptive research methodology was used for this study. A survey was administered to a selected sample from a specific population identified by the researcher as purposive sample. In this way the sample of the study including Bahawalnagar, Lahore, Vehari, Hafizabad and Rawalpindi, districts was selected comprise over five districts of the Punjab (350,5\% of the total population), the researcher tried to make sure to get the representation of the whole population. Surveys are used to obtain data from individuals about themselves, their households, or about larger social institutions (groups/schools). 
Sample surveys are an important tool for collecting and analyzing information from selected individuals. They are widely accepted as a key tool for conducting and applying basic social science research methodology (Rossi, Wright, and Anderson, 1983).

Table 1: Sampling Frame

\begin{tabular}{ccccc}
\hline Districts & Sample Districts & Total SEs & Sample SEs & Male/Female \\
\hline 36 & 05 & 7500 & 350 & $200 / 150$ \\
\hline
\end{tabular}

\section{INSTRUMENTATION}

The Likert scale was used to measure the responses of the educators. The term 'survey' is commonly applied to a research methodology designed to collect data from a specific population, or a sample from that population, and typically utilizes a questionnaire or an interview as the survey instrument (Robson, 1993).

\section{E. DATA COLLECTION}

A five rating scale questionnaire was used to collect data. By personally visiting the schools, getting help from other researcher and through mail and electronic mail the data was collected.

\section{F. DATA ANALYSIS}

The main factors of the study are analyzed by using the statistical method of percentage, Mean and Standard Deviation for the following key elements to measure:

- District and tehsil quota

- Distance from home to duty place

- Provision of transport facilities

- Residence availability

- Functional facilities in school

- Transfer policy

\section{FINDINGS}

On the basis of data analysis the results of the study shown that about $80 \%$ of the teachers are not satisfied with their job in the following way:

- Work Place (W.P)

- Traveling distance( T.D)

- Non availability/inadequate transport facilities(T.F) 
- Social issues with respect to female teachers away home service(S.I)

- Discontinuity of service.(D.S)

- High rate of absentees/latecomers of teachers (H.R.A)

- Problem of Non-availability of teachers remained un-resolved (N.A.T)

- Low standard of primary education( L.S.P.E)

The graph below shows the Mean and Standard deviation of the responses about different factors, analyzed in this study.

\section{Figure 1: Graphical Presentation of Responses (Mean \& S.D)}

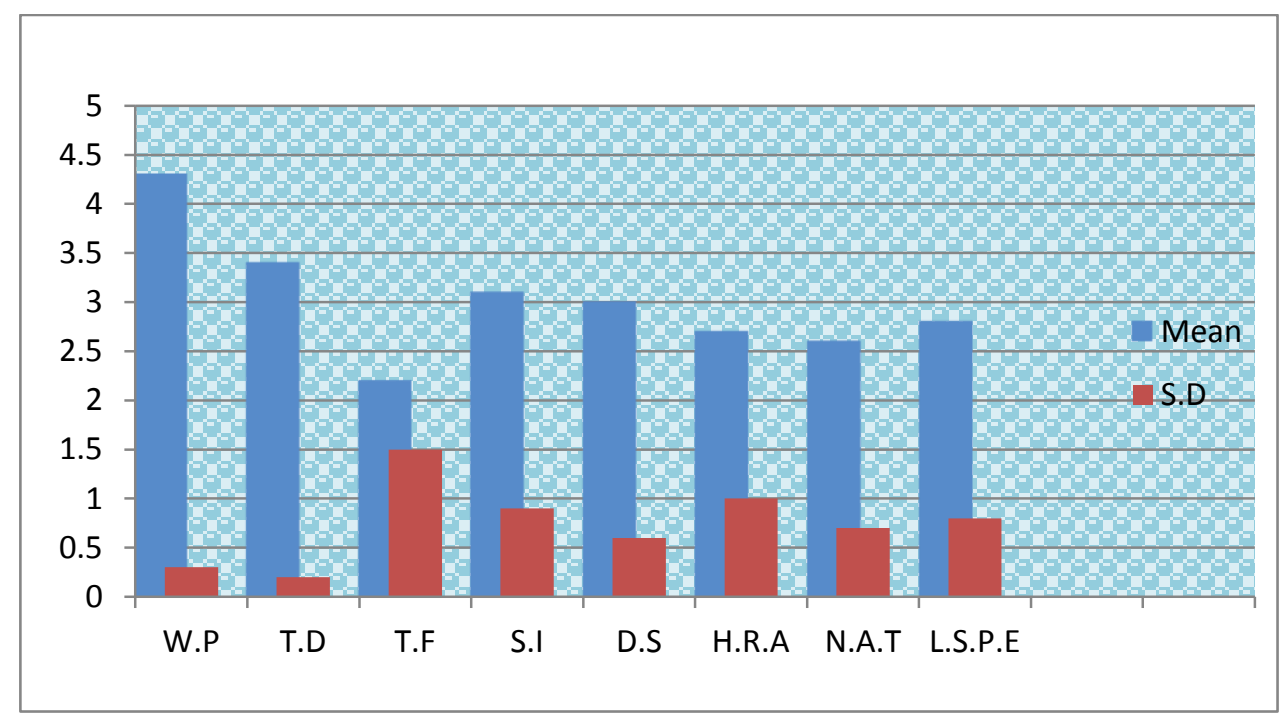

\section{CONCLUSIONS}

The study revealed that the problems of Science Educators can be solved by making the policy more convenient/realistic for local Educators then only the vacancy filling target, from far-flung residents. District merit may be converted to tehsil and union council merit. It is also found that the house and transport facility may be provided with other facilities for teachers with school.

On the basis of deeper and critical investigation, the study found that Primary School Science Educators are most depressed group after being selected as Science Educators they poorly managed without considerations of their gender differences and work place distance from their homes. If the presented suggestion, accepted and implemented the life of primary educators will be professionally sound and primary education may be flourished at its peak. 


\section{RECOMMENDATIONS}

On the basis of this study the following recommendations are presented.

1. The process of recruitment and selection may be readdressed according to the local needs of the area.

2. There may be one category of induction with respect to tehsil and local level only.

3. The number of teachers per schools needs to be increased.

4. The system of teacher training may be improved according to new challenges.

5. The system of accountability may be revisited as the DMO cell is totally remained partial.

\section{REFERENCES}

Adams, T. (1998). Prospective elementary teachers' mathematics subject matter knowledge: American Federation of Teachers (2000) Building a profession: Strengthening teacher Preparation and induction (Report of the K-12 Teacher Education Task Force).Washington, D. C.: Author.

Ashraf, M. (1983). An evaluation of existing supervision practices in Pakistan. 120-126.

Ball, D. L. (1990). Prospective elementary and secondary teachers' understanding of division. Journal of Research in Mathematics Education, 21, 132-144.

Borman, G. D. and Kimball, S.M. (2005). Teacher quality and educational quality: do teachers with higher standards based evaluation rating close students achievements gap? The Elementary school journal, 106 (1), 23-37.

Bregman, J. \& Muhammad, N. (1998). Primary and secondary education structural issues. Islamabad: Jan Publications, 23-31.

British Council (The) (1988). Survey on Teacher Training in Pakistan. Islamabad: The British Council Educational Contracts Department Overseas development Authority.

Farooq, R .A. (1993). Education system of Pakistan: Issues and Problems. Asia society for promotion of Innovation and Reforms in Education. Islamabad: Pakistan, 10-20.

Farooq, R. A. (1990). A Survey Study of Teacher Training in Pakistan. Islamabad: Academy of Educational Planning and Management, Ministry of Education.

Government of Pakistan (1998). National Education Policy 1998-2010. Islamabad: Ministry of Education.

Government of Pakistan (2001).Technical group Meeting on devolution and decentralization, implementation for the education sector. Ministry of Education, Islamabad, Pakistan.

Government of Punjab (2002). Examination and continuous assessment. Lahore: Directorate of Staff Development.

Government of Punjab. (2004). Standard Manual, Elementary, Secondary and Higher Secondary Schools. Education Department, Punjab, Lahore, Pakistan, 10. 
Hayes, L. D. (1987). The crises of education in Pakistan. Lahore: Vanguard Books.

Hoodbhoy, P. (1998). Education and the State: Fifty Years of Pakistan. Karachi: Oxford University Press.

Hussain, S. A. (2001). Education in Pakistan.Allama Iqbal Open University. Islamabad, Pakistan, 1-12.

Illahi, M. A. (1986). The role of the heads of secondary schools. (Unpublished thesis) Allama Iqbal Open University, Islamabad. Pakistan, 12-22.

Khalid, T. (1998). Education: An introduction to educational philosophy and history. Islamabad: National Book Foundation, 22- 35.

Khan, M. S. (1980). Educational Administration. New Delhi: Ashish Publishing, 23-34.

Khan, N. I. (1992). Evaluation of the administrative structure of high (secondary) schools in

Malik, S. R. (1991). The system of education in Pakistan.(pp. 13-20). Islamabad: National Book Foundation.

Mohanty, B. (1990). School administration and supervision. New Delhi: Deep and Deep 1018). Islamabad: Ministry of Education, Pakistan, 20-33.

Punjab. (Unpublished thesis).The University of Punjab, Lahore, Pakistan, 11-22.

Qureshi, S. (2002). Decentralization to district level. Islamabad: Ministry of Education, Pakistan, 31-40.

Rasheed, M. (2004). Educational administration and supervision. Islamabad: Allama lqbal Open University, 145-166.

Rehman, J. U. (2002). Devolution and decentralization: Identification of progress in implementation in education. Islamabad: Ministry of Education, Pakistan, 233-240.

Saleem, M. (2002). Facts and figures. Islamabad: Agha Khan Gee Printers, 07-10.

Shah, D. (2003). Decentralization in the education system of Pakistan: Policies and strategies. Islamabad: Academy of educational Planning Management, Pakistan, 18-23.

Shahzadi, R. \& Perveen, K. (2002). An Evaluation of new educational structure. Unpublished thesis). The University of Punjab, Lahore, Pakistan, 65-68.

Sheikh, M. \& Rasool, M. G. (1998). Allied Material for Teacher Education in Pakistan. Islamabad: AIOU, 40-48.

Siddique, S. A. (1990). Teacher Education in Pakistan. National Training Workshop on Educational Planning and Management for Principals of Teachers Training Institutions, AEPAM, Islamabad, Pakistan, Ministry of Education. 17-19.

Zafar, M. (2003). Fiscal devolution in education. Case study reflecting initial responses. Islamabad: Ministry of education, Pakistan, 34-41. 